\title{
Protective effect of LeMongrass (Cymbopogon citratus) and VITAMIN E ON SODIUM VALPROATE INDUGED TESTICULAR TOXICITY IN RATS
}

\author{
By \\ Abeer E. Elkhamisy \\ Samah A. Elsemelawy \\ Home Economics Dept., \\ Home Economics Dept., \\ Faculty of Specific Education, \\ Faculty of Specific Education, \\ Port Said University, Egypt. \\ Tanta University .Egypt
}

Research Gournal Specific Fducation

Faculty of Specific Education

SMansoura University

ISSUE NO. 46, APRIL. 2017

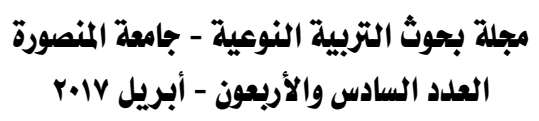




\title{
Protective Effect Of LeMONGRASS (CyMbOPOGON GITRATUS)
} and VITAMIN E ON SODIUM VALPROATE INDUCED TESTICULAR TOXICITY

\section{IN RATS}

\author{
Abeer E. Elkhamisy*
}

Samah A. Elsemelawy

\section{Abstract}

The present study was carried to investigate the effect of extract and powder of Cymbopogon citrates and vitamin $\mathrm{E}$ on the sexual hormonal profiles against testicular toxicity of sodium valproate of normal male rats. The forty two mature male albino rats were divided into seven groups every group of 6 rats. The group control received fed on basal diet, whereas the other five groups received sodium valproate (positive group) the other four groups received Vit. E orally at a dose of $(200 \mathrm{mg} / \mathrm{kg}$ b.wt./day), Lemongrass powder $(100 \mathrm{mg} / \mathrm{kg} /$ diet/day $)$, Lemongrass extract (10 $\mathrm{ml} / \mathrm{kg} / \mathrm{b}$.wt/rat/day), vitamin $\mathrm{E}$ with lemongrass powder and vitamin $\mathrm{E}$ with lemongrass extract, for a period of 6 weeks, caused a significant increase in serum HDL-c, testosterone, serum follicle stimulating hormone level (FSH) ,luteinizing hormone (LH), total antioxidants, superoxide dismutase and glutathion levels compared to positive control group.

Effect on in serum total cholesterol, triglycerides, LDL-c, sexual organs weight (testis, prostate, and seminal vesicles), malondialdehyde were also determined, and was found to be significantly lower in all the administered groups when compared with sodium valproate group. Findings in this study showed that lemongrass powder and extract combination with vitamin $\mathrm{E}$ has a potent protective effect against sodium valproate-induced testicular injury in rats. It also did not exert oxidative damage to the sexual organs and the various hormonal profiles as well as its relative safety and possible use to protect from sodium valproate side effects.

\footnotetext{
* Home Economics Dept., Faculty of Specific Education, Port Said University, Egypt.

${ }^{* *}$ Home Economics Dept., Faculty of Specific Education, Tanta University .Egypt.
} 
Keywords: Cymbopogon citrates - Sodium valproate - Phenolic compounds - Seminal vesicles - Testicular toxicity.

\section{INTRODUCTION}

Lemongrass 'abafado' is widely used in Brazilian folk medicine as a sedative and as a remedy for gastrointestinal disorders. It is also used in many other places to treat feverish conditions (Rauber, et al., 2005). The lemon grass is cultivated mainly in tropical and subtropical regions of Asia, South America and Africa (Ákhila, 2010 and Boukhatem, et al., 2014). Lemongrass consists of luteolin and its 6-C and 7-O-glycosides, isoorientin 2'-O-rhamnoside and isolation of the flavonoids quercetin, kaempferol and apiginin from the aerial parts. The phenolic compounds caffeic acid, elimicin, catecol, hydroquinone and chlorogenic acid are also isolated from the plant (Miean and Mohamed, 2001). Lemongrass also contain z-citral, borneol, estragole, methyleugenol, geranyl acetate, geraniol, beta-myrcene and limonene (Nhu-Trang, et al., 2006 and Pisoschi and Pop, 2015).

Much basic research on the range of efficacies of lemongrass possesses various pharmacological activities such as anti-amoebic, antibacterial, antidiarrheal, antifilarial, antifungal and anti-inflammatory properties. Various other effects like antimalarial, antimutagenicity, antimycobacterial, antioxidants, hypoglycemic and neurobehaviorial (Cheel, et al., 2005). The antioxidant activity attributed to lemongrass and the importance of natural compounds in this sex hormone (Borges, et al., 2015 and Gabriela, et al., 2016).

Sodium valproate (VPA) is widely used throughout the world to treat epilepsy, migraine, chronic headache, bipolar disorder, and as adjuvant chemotherapy. Sodium valproate (VPA) toxicity is an uncommon but potentially fatal cause of idiosyncratic liver injury. Sodium valproate (VPA) toxicity is a cause of testicular injury (Bairy, et al. 2010 and Rossi, 2013). Moreover, Sodium valproate induced oxidative stress and reproductive toxicity in male rats. The aim of the present investigation was to improve the nutritional, healthy values and also to evaluate the influence of lemongrass powder and extract combination with vitamin $E$ has 
effectively alleviated most against sodium valproate-induced testicular toxicity and oxidative stress in male rats.

\section{MATERIAL AND METHOD}

\section{Material and chemicals:}

Lemongrass (Cymbopogon citratus): was obtained from the Agricultural Research Center, Dokki, Giza, Egypt.

\section{Drugs and chemicals:}

Vitamin E (alpha-tocopherol ): was purchased from Pharco Company for Pharmaceutical, Egypt.

Sodium valproate: It is one of products of Sanofi- Synthelaboo Company, France, obtained as oral solution sold under trade name Depakin $^{\circledR}$.

\section{Animals:}

Forty two apparently healthy adult male albino rats that initially weighed approximately $120 \pm 5 \mathrm{~g}$ at age of 7-11 weeks were obtained from Laboratory of Animal Colony, Helwan, Egypt. The animals were allocated in plastic cages with metallic stainless covers. Rats were fed the basal diet (BD) prepared according to Reeves, et al., 1993) for 7 days before the beginning of the experiment for adaptation.

\section{Methods:}

Preparation of Lemongrass extract: was prepared daily as tea by steeping in boiling water and steeping for 20 minutes it gave to rats at dose $(100 \mathrm{mg} / \mathrm{kg})$.

\section{Scavenging effect on 2, 2-diphenyl-1-picrylhydrazyl (DPPH) radicals: \\ The effect of lemongrass on DPPH radical was studied, employing the modified method described earlier by (Yamaguchi, et al., 1998). The radical scavenging activity was measured as a decrease in the absorbance of DPPH and was calculated using the following equation:}

Scavenging effect $\%=\underline{1-\text { A Sample }(517 \mathrm{~nm}) \times 100}$

$$
\text { A Control }(517 \mathrm{~nm})
$$




\section{HPLC analysis of phenolic compounds:}

Phenolic compounds were determined by HPLC according to the method of (Merfort, et al., 1997).

\section{Experimental and grouping of rats:}

Forty two rats were designated into 7 groups (6 rats each) the first main group was fed on the basal diet and kept as negative control group and the rats of second main group ( $\mathrm{n}=36$ rats) fed on the basal diet, and orally sodium valproate (SVP) in dose $500 \mathrm{mg} / \mathrm{kg}$ b.wt/rats/day during the last week of experiment period ( 6 weeks) to induce testicular damage according to according to (Hamza and Amin, 2007).

\section{then divided into 6 groups (each 6 rats) as follows:}

Group (1): BD without any treatment and considered as a positive control $(+v e)$.

Group (2): BD received vitamin E orally at a dose of $200 \mathrm{mg} / \mathrm{kg}$ b.wt./day according to (Shalaby, et al., 2004).

Group (3): BD received lemongrass powder $(100 \mathrm{mg} / \mathrm{kg} / \mathrm{diet} / \mathrm{day})$.

Group (4): BD received lemongrass extract (10 $\mathrm{ml} / \mathrm{kg} / \mathrm{b} . \mathrm{wt} / \mathrm{rats} /$ day).

Group (5): BD received mixture of vitamin $E$ with lemongrass powder.

Group (6): BD received mixture of vitamin $\mathrm{E}$ with lemongrass extract.

During the study, the feed intake was calculated daily and the body weight gain estimated daily.

\section{Biochemical analysis:}

Total lipids were assayed by the method of (Kaplan, 1984). Serum total cholesterol (TC) was performed according to (Henry, et al., 1974). Serum triglycerides (TG) were determined according to the method of Fossati and Prencie, 1982). Serum high density lipoproteins cholesterol (HDL-cholesterol) was assayed according to (Burstein, 1970). The concentration of low density lipoproteins cholesterol (LDL-cholesterol) in serum was estimated by the equation used by (Friedewald, 1972) as follow: LDL- cholesterol $(\mathrm{mg} / \mathrm{dl})=$ Total cholesterol - HDL cholesterol $-(\mathrm{TG} / 5)$.

Serum testosterone concentration, folic lestimulating hormone (FSH) and 
luteinizing hormone ( $\mathrm{LH})$ were determined according to the method of (Maruyama, 1987). The seminal content of epididymis was obtained by cutting of cuda epididymis using surgical blades and squeezed into a clean petri dish. The content was diluted 10 times with $2.9 \%$ sodium citrate solution and thoroughly mixed to estimate the percentage of sperm progressive motility and sperm count as described by (Bearden and Fluquary, 1980). One drop of sperm suspension was withdrawn, smeared on clean glass slide and stained by eosin-nigrosin stain. The stained seminal smears were examined microscopically to determine percentage of sperm viability (ratio of alive/dead) and morphology as described by (Amann, 1982).

Immediately after weighing the genitalia, each testis was homogenised for the biochemical analysis of antioxidant enzymes (Koracevic and Koracevic, 2001), including superoxide dismutase activity (SOD), malondialdehyde (MDA) and glutathione activity (GSH) were determined according to (Nishikimi et al., 1972, Ohkawa et al. 1979, and Beutler et al. 1963) respectively.

\section{Statistical analysis:}

The obtained data were statistically analyzed using computerized SPSS Effects of different treatments were analyzed by one way ANOVA (Analysis of variance) test using Duncan's multiple range test and $\mathrm{p}<0.05$ was used to indicate significance between different groups as described by Snedecor and Cochran (1967).

\section{RESULTS}

Antioxidants content of total antioxidant activity of lemongrass leaves.

The statistical data in Table (1) indicated that, lemongrass Cymbopogon citratus the scavenging activity of lemongrass extract at concentration of $2 \mathrm{mg}, 1.5,1.0$ and $0.5 \mathrm{mg}$ were $(95.11 \%),(92.17 \%),(82.28 \%)$ and $(69.43 \%)$ respectively. 
- Protective Effect of Lemongrass (Cymbopogon citratus) and Vitamin E on Sodium Valproate

\section{The concentrations of phenolic compound in lemongrass extract.}

Many active chemical substances have been investigated of lemongrass Cymbopogon citratus (C. citrates) as shown in Table (2). Lemongrass extract contains high amount of vanillic and syringic compound as it recorded (107.61 and 92.38). While the lowest amount was for P-oHbenzoic as it was (1.81) also it contains vanillic acid, pyrogallo, caffeic, proto catechoic and catechol.

\section{Effect of lemongrass treatment on nutritional parameters in treated rats.}

Table (3) illustrated that, positive control group ( + ve) showed a significant decrease in feed intake and feed efficiency ratio while there was non- significant difference in body weight gain compared to negative control group (- ve ). On the other hand, the treated groups (3, 4, 5, 6 and 7) showed significant increase in these parameters compared with positive control group ( + ve ), and non-significant difference compared with negative control group (ve-).

\section{Effect of lemongrass treatment on lipid profile in treated rats.}

The effects of lemongrass powder and extract on serum lipid profile against sodium valproate induced toxicity in rats are shown in Table (4). The administration of sodium valproate caused significant rise in total lipids, triglycerides, total cholesterol and LDL-C also there was significant decrease in HDL-C. The other treated groups reversed the elevation in lipid profile levels caused by sodium valproate. The treated groups (6 and 7) showed a significant enhancement of lipid parameters.

\section{Effects of lemongrass treatment on the weight of sexual organs in treated rats.}

Data presented in Table (5) illustrated the effects of lemongrass treatment on weight of sexual organs; as positive control group ( + ve ) showed a decrease in the weight of testis and seminal vesicles compared to negative control group (- ve ). Meanwhile, the other treated groups improved these results as it reversed the decreased weight in testis and seminal vesicles caused by sodium valproate. The treated group (6 and 7) 
showed the best results for the weight of sexual organs by recording nonsignificant difference comparing to negative control group.

Effects of lemongrass treatment on sexual hormonal parameters in treated rats.

Results in Table (6) indicated that sodium valproate caused significant decrease in testosterone, LH and FSH levels compared to negative control group (- ve). It could be observed that there was significant improvement in testosterone, $\mathrm{LH}$ and FSH levels on long term treatment with vitamin $E$ with lemongrass powder, lemongrass extract groups (6 and 7) them against sodium valproate as positive control group (+ve).

Effect of lemongrass treatment on serum antioxidant parameters in treated rats.

The effects of lemongrass supplementation on serum antioxidant parameters are shown in Table (7). Sodium valproate caused significant decrease in serum antioxidant enzyme activity, superoxide dismutase (SOD), total antioxidants level and GSH. While there was significant increase in malondialdehyde (MDA) activity compared to negative control group.

Significant increasing was noticed in other treated groups $(3,4,5,6$ and 7) in comparing to positive control group (+ve). Groups (6 and 7) recorded the best results as it shows non-significant difference in comparing to negative control group (-ve).

\section{DISCUSSION}

In the present study, we induced reproductive toxicity with sodium valproate and evaluated the possible protective role of lemongrass extract and powder in restoring the reproductive functions of male rats. Laxminarayana, et al., (2010) found that there is a sloughing of testis's epithelial cells caused by sodium valproate in male rats. Sodium valproate was decrease the testosterone, FSH and LH levels, also decreasing the count and sperm motility in male rats. In agreement with the above reports we have demonstrated that at a dose of $500 \mathrm{mg} / \mathrm{kg}$, sodium valproate produced reproductive toxicity male rats. We found that the testis and seminal 
vesicles weight was significantly lower in sodium valproate treated control rats when compared to that of baseline control and experimental group this is may be due to the sloughing of testis's epithelial cells caused by sodium valproate. These effects were similar to those reported by (Sveberg Roste, et al., 2001) who found that there was a highly significant decrease in testicular weight in rats treated by high dose of sodium valproate.

Our results demonstrate that treatment of male rats with lemongrass powder and extract showed a protective effect against reproductive injury induced by sodium valproate. This effect was manifested by increased weight of the testis, elevated serum testosterone level, FSH level and LH level. The protective effect of Lemongrass on rat reproductive system, reported herein, was partially similar to that reported by (Hanaa, 2013 and Mohamed, et al., 2104)) who concluded that Cymbopogon citratus contains due to their qualitative phytochemical analysis which shows the presence of flavonoids and citral which may be related to its cytoprotective and antioxidant actions in rats.

The mechanism involved in the protective effect of lemongrass against sodium valproate induced reproductive toxicity is unknown but it may be due to the presence of caffeic and chlorogenic acid which are active superoxide anion scavengers can inhibit the lipid peroxidation and the role of antioxidants in the chemistry of oxidative stress (Cheel, et al., 2005 and Pisoschi and Pop, 2015).

Recent phytochemical studies have shown that the Cymbopogan citrates extractwas found to have anti-mutogenic properties (Vinitketkumnuen, et al., 1994). This is due to citral extracted from Cymbopogan citratus, induced death apoptosis in several hematopoietic cancer cell lines in anther study.( Dudai, et al., 2005). This was agreed with (Puatanachokchai, et al., 2002) who cleared that lemongrass contains limonene which possess antitumor activity can protect the prostate of cancer especially when the testosterone level decreases as The prostate gland tissue is also known to be a testosterone dependent organ (Laaksonen, et al., 2004). 
The result showed that administration of both lemongrass extract and powder caused a steady increase in total antioxidants and GSH levels of tested rats after the adminsteration of sodium valproate. The significant increase in the antioxidant parameters of the test animals as compared to the positive control is a reflection of the antioxidant effect of the plant. The study of ( Hanaa, 2013 and Mohamed, et al., 2104) endorse our results as she cleared that lemongrass is found to be more potent and effective hepatoprotective agent as it attenuate the oxidative stress-induced pathological changes. Their leaves are rich with free radical scavenging molecules and it can be used as a potential source of natural antioxidants and nutrients. The dominant constituents of C.Citrus are the flavonoids and triterpenoids which possess antioxidant and hepatoprotective properties (Hesham and Shaeru, 2002). These results corroborate the findings of (Cheel, et al., 2005 and Mohamed, et al., 2104) whey found that lemongrass oil has been evaluated for its antioxidant properties according to the presence of citral and vanilic. Treatment with lemongrass restored MDA and SOD activity, which further highlights their role against sodium valproate-induced injury (Nakamura, et al., 2003). These results indicate that the lemongrass seems to be an effective antioxidant agent when it used in infusions with high concentration (Gabriela, et al., 2016).

\section{CONCLUSION}

This study suggests that sodium valproate causes testicular toxicity, but the flavonoid compound and the total antioxidant activity of lemongrass extract and powder combination with vitamin $\mathrm{E}$ are protective in terms of sexual organs weight and sexual hormonal parameters. Both of them were also restored by lemongrass confirming its protective effect. This action of lemongrass may be closely related to its antioxidant, anti-inflammatory and antiapoptotic property, which needs further research.

Table (1): Scavenging effect (\%) of lemongrass extract on (DPPH) radical

\begin{tabular}{|c|c|c|c|c|}
\hline \hline $\begin{array}{c}\text { lemongrass } \\
\text { extract }\end{array}$ & $\mathbf{2 m g}$ & $\mathbf{1 . 5 m g}$ & $\mathbf{1 . 0} \mathbf{m g}$ & $\mathbf{0 . 5} \mathbf{m g}$ \\
\cline { 2 - 5 } & $95.11 \pm 0.88$ & $92.17 \pm 1.78$ & $82.28 \pm 1.12$ & $69.43 \pm 2.97$ \\
\hline
\end{tabular}

Each value is the Mean \pm SD 
Table (2): Percentage of polyphenolic compounds of lemongrass extracts $(\mathrm{mg} / 100 \mathrm{~g})$

\begin{tabular}{||c|c||}
\hline Phenolic Compound & Mass (mg/100g) \\
\hline \hline Syringic & 92.38 \\
\hline Pyrogallo & 17.61 \\
\hline Proto catechoic & 8.49 \\
\hline Vanillic acid & 21.18 \\
\hline Catechol & 3.54 \\
\hline P-oH-benzoic & 1.81 \\
\hline Caffeic & 9.38 \\
\hline Vanillic & 107.61 \\
\hline
\end{tabular}

Table (3): Effects of lemongrass and Vit. E on body weight gain, feed intake and food efficiency ratio (FER) in protective group

\begin{tabular}{|c|c|c|c|}
\hline \multirow{2}{*}{ Groups } & Weight gain & Feed intake & \multirow{2}{*}{$\begin{array}{c}\text { FER } \\
(\%) \\
\end{array}$} \\
\hline & \multicolumn{2}{|c|}{$(\mathrm{g})$} & \\
\hline Group 1 & $123.32 \pm 3.35 \mathrm{a}$ & $15.94 \pm 2.20 \mathrm{a}$ & $0.255 \pm 0.03 \mathrm{a}$ \\
\hline Group 2 & $121.24 \pm 5.21 \mathrm{a}$ & $11.08 \pm 2.03 \mathrm{~b}$ & $0.175 \pm 0.02 \mathrm{~b}$ \\
\hline Group 3 & $120.32 \pm 3.99 \mathrm{a}$ & $15.25 \pm 2.32 \mathrm{a}$ & $0.246 \pm 0.04 \mathrm{a}$ \\
\hline Group 4 & $124.91 \pm 5.67 \mathrm{a}$ & $15.46 \pm 2.21 \mathrm{a}$ & $0.237 \pm 0.03 \mathrm{a}$ \\
\hline Group 5 & $125.22 \pm 3.86 \mathrm{a}$ & $15.68 \pm 2.92 \mathrm{a}$ & $0.250 \pm 0.04 \mathrm{a}$ \\
\hline Group 6 & $124.52 \pm 3.35 \mathrm{a}$ & $15.94 \pm 2.20 \mathrm{a}$ & $0.255 \pm 0.03 \mathrm{a}$ \\
\hline Group 7 & $123.42 \pm 3.24 \mathrm{a}$ & $15.54 \pm 2.27 \mathrm{a}$ & $0.254 \pm 0.03 \mathrm{a}$ \\
\hline
\end{tabular}

Mean values in each column having different superscript $(a, b)$ are significant. 
مجلة بحوث التربية النوعية - علد T2 - أبريل r.lV

Table (4): Effects of lemongrass and Vit. E on lipid parameters in protective group

\begin{tabular}{||c|c|c|c|c||}
\hline \multirow{2}{*}{ Groups } & TC & TG & HDL-c & LDL-c \\
\cline { 2 - 6 } & \multicolumn{4}{|c||}{$\mathrm{mg} / \mathrm{dl}$} \\
\hline \hline Group 1 & $101.21 \pm 24.33 \mathrm{e}$ & $50.03 \pm 12.62 \mathrm{e}$ & $48.86 \pm 3.11 \mathrm{a}$ & $49.15 \pm 8.43 \mathrm{~d}$ \\
\hline Group 2 & $141.19 \pm 29.12 \mathrm{a}$ & $80.43 \pm 14.82 \mathrm{a}$ & $22.58 \pm 2.54 \mathrm{~d}$ & $89.12 \pm 12.43 \mathrm{a}$ \\
\hline Group 3 & $116.27 \pm 26.54 \mathrm{c}$ & $55.27 \pm 23.03 \mathrm{c}$ & $37.97 \pm 2.66 \mathrm{c}$ & $68.06 \pm 8.37 \mathrm{~b}$ \\
\hline Group 4 & $117.14 \pm 27.65 \mathrm{c}$ & $56.17 \pm 24.34 \mathrm{bc}$ & $46.60 \pm 1.93 \mathrm{a}$ & $55.46 \pm 5.36 \mathrm{~b} \mathrm{c}$ \\
\hline Group 5 & $125.48 \pm 24.28 \mathrm{~b}$ & $64.324 \pm 4.083 \mathrm{~b}$ & $45.02 \pm 2.76 \mathrm{~b}$ & $51.58 \pm 15.06 \mathrm{c}$ \\
\hline Group 6 & $103.27 \pm 22.54 \mathrm{~d}$ & $56.194 \pm 3.05 \mathrm{c}$ & $46.72 \pm 2.26 \mathrm{a}$ & $50.06 \pm 11.47 \mathrm{c}$ \\
\hline Group 7 & $101.78 \pm 24.21 \mathrm{~d}$ & $52.194 \pm 3.46 \mathrm{~d}$ & $48.17 \pm 2.73 \mathrm{a}$ & $49.66 \pm 8.35 \mathrm{c}$ \\
\hline
\end{tabular}

Mean values in each column having different superscript $(a, b)$ are significant

TC: Total cholesterol TG: Triglyceride HDLc: High density lipoprotein cholesterol LDLc: Low density lipoprotein cholesterol

Table (5): Effects of lemongrass and Vit. E on the weight of sexual organs in protective group

\begin{tabular}{|c|c|c||}
\hline \multirow{2}{*}{ Groups } & Testis & Seminal vesicles \\
\hline \hline Group 1 & $2.41 \pm 0.23 \mathrm{a}$ & $0.79 \pm 0.07 \mathrm{a}$ \\
\hline & \multicolumn{2}{|c||}{ Relative weight of organs (g/100g b.wt.) } \\
\hline Group 2 & $1.03 \pm 0.20 \mathrm{~d}$ & $0.40 \pm 0.03 \mathrm{~d}$ \\
\hline Group 3 & $1.85 \pm 0.20 \mathrm{~b}$ & $0.65 \pm 0.07 \mathrm{c}$ \\
\hline Group 4 & $1.75 \pm 0.26 \mathrm{bc}$ & $0.71 \pm 0.16 \mathrm{~b}$ \\
\hline Group 5 & $1.89 \pm 0.14 \mathrm{~b}$ & $0.73 \pm 0.06 \mathrm{~b}$ \\
\hline Group 6 & $2.40 \pm 0.26 \mathrm{a}$ & $0.75 \pm 0.11 \mathrm{~b}$ \\
\hline Group 7 & $2.39 \pm 0.14 \mathrm{a}$ & $0.75 \pm 0.12 \mathrm{~b}$ \\
\hline
\end{tabular}

Mean values in each column having different superscript $(a, b)$ are significant. 
Table (6): Effects of lemongrass and Vit. E on sexual hormonal parameters in protective group

\begin{tabular}{||c|c|c|c||}
\hline \multirow{2}{*}{ Groups } & Testosterone & Follicle Stimulating & Luteinizing \\
\cline { 2 - 4 } & \multicolumn{3}{|c||}{$\mathbf{n g} / \mathbf{m L}$} \\
\hline \hline Group 1 & $26.82 \pm 1.7 \mathrm{a}$ & $160.38 \pm 6.75 \mathrm{a}$ & $4.28 \pm 0.76 \mathrm{a}$ \\
\hline Group 2 & $14.03 \pm 2.01 \mathrm{~d}$ & $92.17 \pm 5.99 \mathrm{~d}$ & $1.78 \pm 1.16 \mathrm{~d}$ \\
\hline Group 3 & $20.12 \pm 3.01 \mathrm{c}$ & $138.98 \pm 9.65 \mathrm{~b}$ & $2.92 \pm 0.96 \mathrm{c}$ \\
\hline Group 4 & $23.33 \pm 4.81 \mathrm{c}$ & $144.42 \pm 5.80 \mathrm{c}$ & $3.44 \pm 0.52 \mathrm{bc}$ \\
\hline Group 5 & $24.01 \pm 4.10 \mathrm{~b}$ & $156.60 \pm 8.09 \mathrm{c}$ & $3.57 \pm 0.37 \mathrm{~b}$ \\
\hline Group 6 & $25.81 \pm 8.34 \mathrm{ab}$ & $159.39 \pm 8.80 \mathrm{~b}$ & $3.96 \pm 0.96 \mathrm{~b}$ \\
\hline Group 7 & $26.41 \pm 9.64 \mathrm{ab}$ & $159.99 \pm 8.90 \mathrm{~b}$ & $4.06 \pm 0.56 \mathrm{~b}$ \\
\hline
\end{tabular}

Mean values in each column having different superscript $(a, b)$ are significant.

Table (7): Effects of lemongrass and Vit. E on antioxidant parameters in protective group

\begin{tabular}{|c|c|c|c|c|}
\hline \multirow{2}{*}{ Groups } & $\begin{array}{c}\text { Total } \\
\text { Antioxidants }\end{array}$ & Malondialdehyde & \multirow[t]{2}{*}{$\begin{array}{c}\text { Superoxide dismutase } \\
(\mathrm{U} / \mathrm{mL})\end{array}$} & \multirow[t]{2}{*}{$\begin{array}{c}\text { Glutathion } \\
\qquad(\mu / \mathrm{mg})\end{array}$} \\
\hline & \multicolumn{2}{|c|}{$(\mathrm{mmol} / \mathrm{L})$} & & \\
\hline Group 1 & $3.38 \pm 0.75 \mathrm{a}$ & $5.64 \pm 0.39 \mathrm{e}$ & $210.67 \pm 11.02 \mathrm{a}$ & $132.21 \pm 1.06 \mathrm{a}$ \\
\hline Group 2 & $1.17 \pm 0.55 \mathrm{~d}$ & $12.17 \pm 0.38 \mathrm{a}$ & $108.33 \pm 9.02 \mathrm{f}$ & $53.32 \pm 0.76 \mathrm{~d}$ \\
\hline Group 3 & $2.68 \pm 0.65 \mathrm{~b}$ & $9.10 \pm 0.21 \mathrm{~b}$ & $150.17 \pm 5.10 \mathrm{e}$ & $92.22 \pm 0.60 \mathrm{c}$ \\
\hline Group 4 & $2.58 \pm 0.80 \mathrm{~b}$ & $7.50 \pm 0.40 \mathrm{c}$ & $170.63 \pm 7.07 \mathrm{~d}$ & $98.42 \pm 0.70 \mathrm{c}$ \\
\hline Group 5 & $2.61 \pm 0.09 \mathrm{~b}$ & $5.43 \pm 0.41 \mathrm{~d}$ & $197.67 \pm 7.51 \mathrm{c}$ & $121.43 \pm 0.50 \mathrm{~b}$ \\
\hline Group 6 & $3.65 \pm 1.70 \mathrm{ab}$ & $5.51 \pm 0.92 \mathrm{e}$ & $202.33 \pm 10.08 \mathrm{~b}$ & $123.18 \pm 0.07 \mathrm{~b}$ \\
\hline Group 7 & $3.69 \pm 1.80 \mathrm{ab}$ & $5.62 \pm 0.99 \mathrm{e}$ & $208.45 \pm 10.39 \mathrm{ab}$ & $125.18 \pm 0.08 \mathrm{~b}$ \\
\hline
\end{tabular}

Mean values in each column having different superscript $(a, b)$ are significant. 


\section{REFRECENS}

- Amann R.P.(1982): Fertilizing potential in vitro of semen from young beef bulls containing a high or low percentage of sperm with a proximal droplet. Theriogenology 54 (9): 1499-1515.

- Ákhila, A. (2010): Essential Oil-bearing Grasses: the genus Cymbopogon. New York: CRC Press., 2(3): 101-111.

- Bairy, L.; Paul, V., and Rao, Y. (2010): Reproductive toxicity of sodium valproate in male rats. Indian J Pharmacol. 42(2): 90-4.

- Bearden, H.J., and Fluquary, J. (1980): Applied animal reproduction. Restore Publishing Co. Inc., Reston, USA, 158-160.

- Boukhatem, M. N.; Ferhat, M. A., and Kebir, H. T. (2014): Lemon grass (Cymbopogon citratus) essential oil as a potent anti-inflammatory and antifungal drugs. Libyan Journal of Medicine, 19(9): 925431-925436.

- Beutler, E.; Duron, O., and Kelly, M.B. (1963): Determination of reduced glutathione in tissue homogenate. J. Lab Clin. Med. 61: 882-884.

- Borges, T. F. C.; Tamazato, A. P. S., and Ferreira, M. S. C. (2015): Female sex hormone therapy and thromboembolic phenomena: Literature Review. Revista Ciências em Saúde, 5(2): 158-160.

- Burstein, M. (1970): Rapid method for isolation of lipoproteins from human serum by precipitation with poly-anion. J. lipid Research, 11: 583- 588.

- Cheel, J.; Theoduloz, C.; Rodríguez, J., and Schmeda-Hirschmann, G. (2005): Free radical scavengers and antioxidants from Lemongrass (Cymbopogon citratus (DC) Stapf) J Agric Food Chem., 53 (7):2511-7.

- Dudai, N.; Weinstein, Y.; Krup, M.; Rabinski, T., and Ofir, R. (2005): Citral is a new inducer of caspase-3 in tumor cell lines. Planta Med. 71(5):484488.

- Fossati, P., and Prencipel, L. (1982): Determination of triglycerides,bicon diagnostics, made in germany. Clinical Chemistry. 28: 2077-2078.

- Friedewald, W.T., (1972): Determination of HDL. Clin. Chem.; 498:499.

- Gabriela Tassotti Gelatti; Roberta Cattaneo Horn; Natacha Cossettin Mori; Evelise Moraes Berlezi; Ana Caroline Tissiani; Mariana Spanamberg Mayer; and Daiana Meggiolaro Gewehr ( 2016): Effect of cymbopogon 
- Protective Effect of Lemongrass (Cymbopogon citratus) and Vitamin E on Sodium Valproate

citratus on oxidative stress markers in erythrocytes from postmenopausal woman: A Pilot Study. Journal of Plant Studies., 5, (1): 1927-0461.

- Hamza, A.A., and Amin, A. (2007): Apium graveolens modulates sodium valproate induced reproductive toxicity in male rats. J.Expe. Zool. 307(4):199206.

- Hanaa F. El Mehiry, (2013): Hepatoprotective effect of lemongrass (Cymbopogon Citratus) against oxyteracycline -induced fatty liver in male rats. The New Egyptian Jouranl of Medicine. 3 : 1110-1946.

- Henry, R., Cannon, D. and Winkelman, J. (1974): Clinical Chemistry Principles and Techniques, Harper and Row. New York., 1440-1452.

- Hesham, R.E., and Shaeru, N. (2002): Chemistry of bioflavonoids. Indian J Pharm Educ., 36:191-194.

- Kaplan, A. (1984): Quantitative determination of total lipids. Clin. Chem., 22: 919-932.

- Koracevic, D., and Koracevic, G. (2001): Determination of TAC in serum. J. Clin. Pathol. 54: 356 - 361.

- Laaksonen, D.E.; Niskanen, L.; Punnonen, K.; Nyyssonen, K.; Tuomainen, T.P., and Valkonen, V.P. (2004): Testosterone and sex hormone-binding globulin predict the metabolic syndrome and diabetes in middleaged men. Diabetes Care. 27: 1036 - 1041.

- Laxminarayana Bairy; Vijay Paul, and Yeshwanth Rao, (2010):

Reproductive toxicity of sodium valproate in male rats... Indian J Pharmacol., 42(2): 90-94.

- Maruyama, Y. (1987): Sex-steroid binding, plasma protein (SBP), testosterone, estradiol and DHEA in prepuberty and puberty. Acta.Endocrinol. 114: 60-67.

- Merfort, l.; Wary, V.S.M., and Willuhan, G. (1997): Flavonol triglycerides from seeds of Nigella Sativa. Phetochem. 46(2):359-363.

- Miean, K.H.; and Mohamed, S. (2001): Flavonoid (myricetin, quercetin, kaempferol, luteolin, and apigenin) content of edible tropical plants. J Agric Food Chem., 49(6):3106-3112.

- Mohamed, S. El-Dashlouty; Asheaf Abd El-Aziz, and Mona Galal Mohamed (2014): Using lemon grass ( Cymbopogon Citratus) powder and lemon grass tea as hypoglycemic. Egyptian J. of Nutrition 29,(4): 1-27. 
- Nakamura, Y., Miyamoto, M., Murakami, A., Ohigashi, H., Osawa, T., and Uchida, K. (2003): A phase II detoxification enzyme inducer from lemongrass: identification of citral and involvement of electrophilic reaction in the enzyme induction. Biochem Biophys Res Commun., 302(3):593-600.

- Nhu-Trang, T.T.; Casabianca, H., and Grenier-Loustalot, M.F. (2006): Authenticity control of essential oils containing citronellal and citral by chiral and stable-isotope gas-chromatographic analysis. Anal Bioanal Chem.; 386(78):2141-2152.

- Nishikimi, M.; Roa, N.A., and Yogi, K. (1972): Determination of superoxide dismutase in tissue homogenate. Biochem. Bioph. Res.Common., 46: 849 - 854.

- Ohkawa, H.; Ohishi, N., and Yagi, K. (1979): Assay for lipid peroxides in animal tissues by thiobarbituric acid reaction. Anal Bio., 95: 351-358.

- Pisoschi, A. M., and Pop, A. (2015): The role of antioxidants in the chemistry of oxidative stress: a review. European Journal of Medicinal Chemistry, 97: 55-74.

- Puatanachokchai, R.; Kishida, H.; Denda, A.; Murata, N.; Konishi, Y.; Vinitketkumnuen, U., and Nakae, D. (2002): Inhibitory effects of lemon grass (Cymbopogon citratus, Stapf) extract on the early phase of hepatocarcinogenesis after initiation with diethylnitrosamine in male Fischer 344 rats. Cancer Lett 9-8183(1): 9-15.

- Rauber, S.; Guterres, S.S., and Schapoval, E.E. (2005): LC determination of citral in Cymbopogon citratus volatile oil. J Pharm Biomed Anal., 37:597-601.

- Reeves P.G.; Nielson F.H., and Fahmy G.C. (1993): Reports of the American Institute of Nutrition, Adhoc Wiling Committee on reformulation of the AIN 93. Rodent Diet. J. Nutri., 123: 1939-51

- Rossi, S. D. (2013): Australian Medicines Handbook (2013 ed.). Adelaide: The Australian Medicines Handbook Unit Trust., 978: 9805790-98057903

- Shalaby, A. M .; Khattab, Y. M., and Abdel rahman, A.M.(2004): Response of Nile tilapia, Oreochromis niloticus, fingerlings to diets supplemented with different levels of fenugreek seeds (Hulba) J Agric Mansoura Univ., 29:22312242.

- Snedecor, G.W., and W.G. Cochran, (1967): Statistical Methods. 7 Ed. the Iowa State University Press, Ames, Iowa, U.S.A. 
- Sveberg Roste, L.; Tauboll, E.; Berner, A.; Berg, K.A.;Aleksandersen, M., and Gjerstad, L., (2001): Morphological changes in the testis after longterm valproate treatment in male Wistar rats. Seizure.,10:559-65.

- Vinitketkumnuen, U.; Puatanachokchai, R.; Kongtawelert, P.; Lertprasertsuke, N., and Matsushima, T. (1994): Antimutagenicity of lemon grass (Cymbopogon citratus Stapf) to various known mutagens in salmonella mutation assay. Mutat Res. 341(1):71-75.

- Yamaguchi, T.; Takamura, H.; Matoba, T., and Terao, J. (1998): HPLC method for evaluation of the free radical-scavenging activity of foods by using 1 , 1,-diphenyl-2-picrylhydrazyl. Bioscience Biotechnology Biochemistry, 62: 1201 -1204 . 


\title{
التأثير الوقائي لهشيشة اليسمون وفيتاهين هـ ضد تسميم الفصية الناجم
}

\author{
عن الاصابة بفالبروات الصوديوم في ذكور الفئران

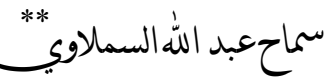

\section{الملاخص العربي}

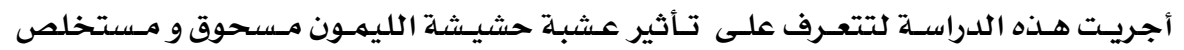

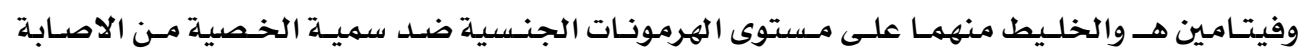

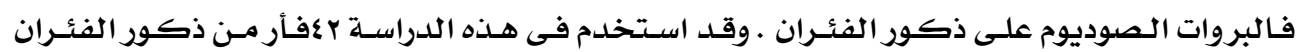

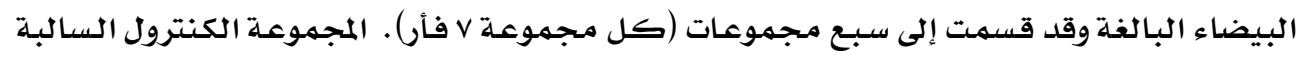

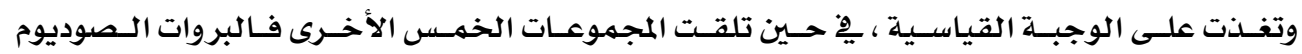

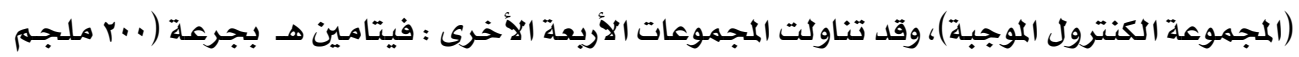

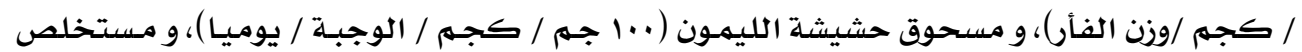

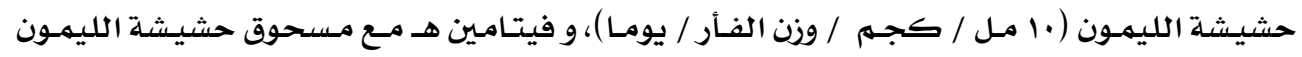

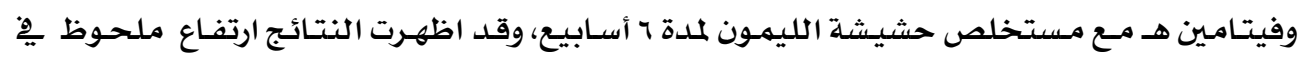

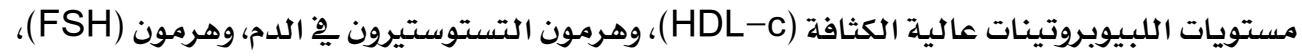

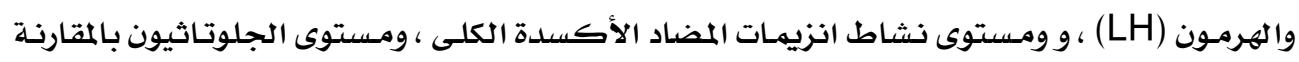

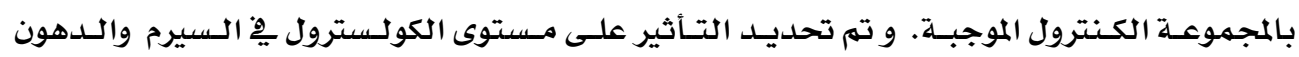

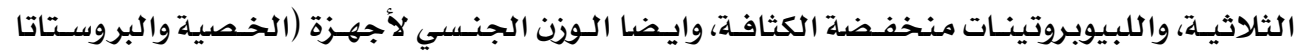

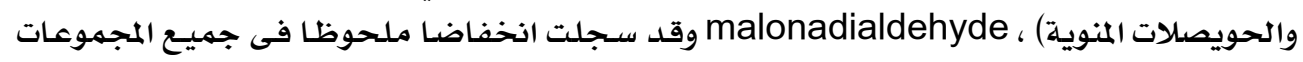

$$
\text { المعالجة مقارنة بالمجموعة الكنترول الموجبة (فالبروات الصوديوم). }
$$

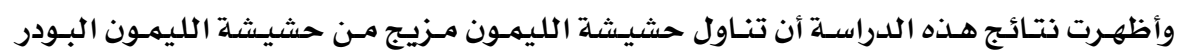

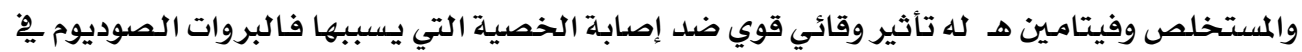

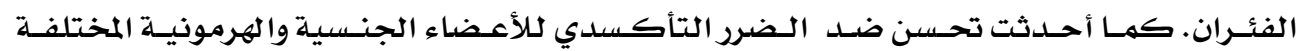

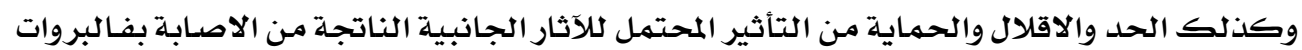

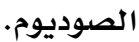

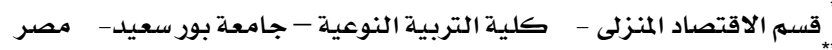

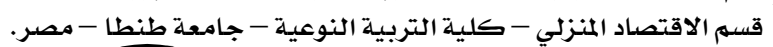

